\title{
Author Correction: Factors Associated with Variation in Cuticular Hydrocarbon Profiles in the Navel Orangeworm, Amyelois transitella (Lepidoptera: Pyralidae)
}

\author{
Esther N. Ngumbi ${ }^{1}$ - Lawrence M. Hanks ${ }^{1} \cdot$ Andrew V. Suarez ${ }^{1} \cdot$ Jocelyn G. Millar $^{2} \cdot$ May R. Berenbaum $^{1}$
}

Published online: 4 February 2020

(C) Springer Science+Business Media, LLC, part of Springer Nature 2020

Author Correction: Journal of Chemical Ecology (2020) 46(1):40-47

https://doi.org/10.1007/s10886-019-01129-6

The original version of this article unfortunately contained a mistake. When filing the final publication details, we failed to include the following statement in our Acknowledgments paragraph: We thank the Almond Board of California for research funding.

The authors apologize for this oversight and for any confusion it may have caused.

The online version of the original article can be found at https://doi.org/ 10.1007/s10886-019-01129-6

Esther N. Ngumbi

enn@illinois.edu

1 Department of Entomology, University of Illinois at Urbana-Champaign, Urbana, IL 61801, USA

2 Department of Entomology, University of California, Riverside, CA 92521, USA 